\title{
Research on the Feasibility of Enterprise IPO Registration System in China
}

\author{
yiwei Xie ${ }^{1, \text { a }}$ \\ ${ }^{1}$ Northwest University; Xi'an, Shannxi, China, 710127 \\ ${ }^{a}$ email
}

Keywords: Feasibility, Enterprise, IPO Registration System

\begin{abstract}
With the development of China's securities market, stock issuance impediment to excessive administrative intervention in the process of China's stock market is gradually emerging. Nearly two years, the market for the implementation of the registration system a loud voice, regulators have repeatedly revealed the future to implement the registration system signals. Based on the analysis of the implementation of the registration system feasibility and effects that have initially implemented registration system conditions and the registration system will greatly improve the efficiency of capital markets, and help to rebuild a new, healthy stock market.
\end{abstract}

\section{Introduction}

US stock market has a hundred years of history of the use of the registration system has two basic conditions: First, the regulatory body has efficient regulatory capacity and means; the second is the issuer and the securities intermediary has a sense of integrity and legal awareness. Clearly, China's securities market has not yet adopted US-style step cancel approval, a direct transition to the registration system conditions and this period requires a gradual build and improves the process. In this process, in order to meet registration system construction, prepare the ground for the stock market, a very important aspect is to do information disclosure.

\section{The Connotation of Registration System}

Issuance of securities registration system known as "formal examination system" refers to the issuer applies for issuing shares, various types of information required by law to be disclosed fully and accurately report to securities regulators, securities regulators will declare comprehensive document, true and timeliness of the formal examination, without the issuer's qualification for substantive reviews and value judgments. In layman's terms is no longer a rigorous examination, as long as the company announced details of its all financial, basically it can issue stock, so the implementation of the registration system is open system, which requires companies to issue securities offer the issuers related all the information.

\section{The Reasons of Chinese Securities Market Gradually Introduce Registration System}

Registration system and approval system has certain advantages in comparison, but the current stock market environment is not suitable for immediate use of the registration system, but should be gradually introduced registration system. At present, China's securities market shares prevailing high valuation, high premium phenomenon, but this does not mean that China's listed companies are optimistic about the market, especially companies, but because of the small number of new companies listed on the stock market did not reach "equilibrium scale" state, corporate investors can choose fewer, and some listed companies not because of the expansion of business scale real financing needs, but in order to achieve financing through "misappropriating" purposes. In fact, many real financing needs, the company has development potential, such as some tech companies in China's capital market are difficult listing qualifications, which makes China's securities market has not really play the resource allocation function.

Consistent trading stock market and the issuance of general business principles, voluntary 
transactions between companies and investors, self-financing, regulatory authorities instead of investors to determine a company's good or bad: even accurate judgment also hampered some companies really need financing ; If the judgment is incorrect, a certain rent-seeking behavior, but in a greater waste of resources, it is the responsibility of the regulatory authorities should be shifted from the company's good or bad judgment truthfully or not regulation of information disclosure. Regulators master! "Power \# approved the company's application for listing has decided powers, and can not achieve," improving the quality of listed companies, "the self-assigned mission, but had a high price-earnings ratio, high premiums and other effective capital markets should not be situation occurs, there has been a listed company financial fraud, false accounting information disclosure environment and other circumstances, there has been a case of a company listed on the decline in operating results, which are not normal.

At present, China's securities market still can not replace the missing securities regulatory authorities listed companies to investors to determine whether it is "good" the company's responsibility, but this responsibility will increasingly weaken, and to ensure that information disclosure of listed companies will be more truthful of strengthening, which is the inevitable choice of the development of China's securities market, and this makes the choice to introduce basic registration system is becoming more and more solid, while securities regulators gradually increase its regulatory efficiency, gradually increase the quality of information disclosure of listed companies when , China should gradually introduce IPO registration system.

\section{The Conditions of the Implementation of Registration System in China's Securities Market}

The Securities Regulatory Requirements under the Registration System. US securities regulators to implement the registration system is divided into two parts, one government-led regulatory system, the second is monitoring system professional services organization. When the information disclosure and business practices in violation of the securities laws, the right to investigate suspected violations of the securities laws of behavior may also be responsible for the legal proceedings, the legal responsibilities include criminal, civil and administrative responsibility to severe punitive measures urged listed companies to disclose information truthfully. Government-led regulatory system also includes an auxiliary regulatory organization, the self-regulatory organizations such as the American Stock Exchange and the Securities Association of registration, they review the company's listing qualifications, and closely monitor the performance of its listing and the company does not meet the disclosure requirements give delisted. Supervision system and professional services, including listed companies related to various types of market intermediaries and personnel such as certified public accountants, attorneys, sponsors, investment banks. They securities market in accordance with the relevant provisions of the construction, can provide independent expert advice on a wide range of business issues and provide services for listed companies and investors.

Registration systems for securities regulation requirements are more stringent than the approval system, reflected in the promotion of regulatory efficiency and regulatory standards have strict requirements. At present, China is to improve the implementation of the efficiency of the registration system of securities regulation first step is to solve China's current securities regulation is not the lack of legal norms for listed companies' information disclosure, more a lack of execution is regulated. The securities regulatory authorities should gradually improve the information disclosure of listed truthfully legal consequences explicitly listed companies do not truthfully disclose the legal responsibility for the information. At the same time, it should promptly investigate violations truthfully disclose the information, and punish those responsible for accountability, information disclosure, until the abolition of the law firm's listing status, so as to serve as a warning, and to ensure that the stock market does not truthfully disclose information conduct timely corrected. Regulatory efficiency in order to dispel the information is not truthfully disclose the company's chances to increase the probability of isolated information is not truthful disclosure, increased responsibility and liability company (not truthfully disclose the legal costs), so that the issuing company dare not truthfully disclosure of information. 
The Information Disclosure Requirements under the Registration System. SFC February 1, 2007 release of "Corporate Disclosure management approach", aimed at strengthening the information disclosure of listed companies, to protect the legitimate interests of investors, improve the quality of listed companies, and promote the healthy development of the stock market. It is stipulated that the information disclosure of listed companies in the prospectus, the prospectus and the listing announcement and periodic reports, regular reports, also clearly the responsibilities of the company related to the disclosure of information, but the law does not explicitly violate the principle of information disclosure of listed companies and legal liability related personnel, which means regulators for warning information disclosure of listed companies is not enough. A major premise is the authenticity of the information the US stock market to implement the registration system is fully liable by the company, forcing issuers to establish the integrity awareness and legal awareness. Once the securities regulatory authorities or the information disclosure of listed companies fraud, forgery, all sign the document of company executives and securities intermediaries who are required to accept responsibility for criminal penalties, usually about 20 years or more in prison, as well as financial penalties. It is this very high costs of crime such listed companies dare not truthfully disclose information, the disclosure of false information so as not to rush and lose eligibility listed companies already listed.

Meanwhile, the information disclosure system of registration requirements for intermediaries under the supervision of listed companies to fulfill the requirements of the authenticity of the information, such as the prospectus of the legal opinion signed and need a lawyer responsible for periodic report financial statements authenticity signed by a certified public accountant and is responsible for. US securities regulatory authorities at the same time do not truthfully disclose information of listed companies proposed penalties, also on the agency made the punishment until the disqualification agency services. Only proposed harsh penalties for not dutifully intermediaries to ensure that agencies performed their duties, will be under the supervision of this layer after layer of supervision of the securities regulatory authorities, truthfully securities regulatory authorities to check the information disclosure of listed companies work inspection agency truthfully whether due diligence, due diligence and not to punish the agency, urged other listed companies and intermediaries are conscientiously fulfill faithfully the duty of disclosure of information, such as layers of oversight to ensure that the quality of information disclosure of listed companies.

Additional Support of Stock Market Construction. The stock market not only for the gradual introduction of the registration system of securities regulation and information disclosure requests, and other aspects of the construction work on the stock market also made coordination requirements, such as the effectiveness of the audit market, the quality of service intermediaries, the securities regulatory authorities of the securities issued new problems after power to the underwriter and the like. The latter, for example, the lead underwriter mastered release of power after also bear a certain amount of risk, which is the lead underwriter of the scale and quality services for their high demands, such as improving the legal system of the securities market, and gradually make up for stock market the law is not clear on the terms to define the legal responsibility of information disclosure, the information disclosure of listed companies to determine the legal consequences of not truthfully.

Other construction backed securities registration system is conducive to the implementation of the stock market in our country, such as the stock market compensation mechanism, the class action system and delisting mechanism combined with a series of systems to maximize the effectiveness of the registration system. Such as the US class action lawsuits is an effective way to protect shareholders' equity of justice, is the most commonly used means of civil claims of shareholders, once the securities fraud occurs, investors can hire a lawyer on behalf of their commencement of collective proceedings. In the investor class action lawyers are able to obtain the amount of compensation is about $20 \%-30 \%$ of the legal fees, so the United States will spare no effort to provide investors lawyer class action services. And China's current legal system is not perfect securities litigation, many investors lack of litigation when investment losses suffered, so gradually improve China's securities litigation legal system construction delay. 


\section{The Measures to be Taken for the Smooth Progress of the Registration System}

Registration system needs to implement a number of supporting measures: First, we should accelerate the transformation of the functions of the Commission. Commission should function is to maintain order in the capital market and protect investors' legitimate rights and interests. However, under the approval system, the Commission to focus on the IPO approval, the transition from the approval system to the registration system, the Commission first needs to be done to separate supervision and examination. Enterprise and IPO first to review the stock exchange, and then submitted to the Commission review, the Commission of the Company to be issued without examination as to substance and value judgments, but rather to review the information disclosed is true, so as to promote the approval system to the registration system transition .

Secondly, strengthen information disclosure quality. The key is to implement the registration system information disclosed by listed companies to be true and accurate. Through the implementation of the main responsibility for issuers and intermediaries to promote the homing responsible parties, to strengthen the authenticity, accuracy and completeness of information disclosure, improve the quality of issuer disclosure, suppression of false information, revealing the full potential risks and possible affect investor decision-making information.

Thirdly, to further improve laws and regulations issued audit. Currently our legal norms Issuance System is based mainly "Company Law", "Securities Law", "Provisional Regulations on stock issuance and transaction management," as well as the relevant guidelines published by the securities regulatory authorities, no systematic sponsor legal system, many provisions there are loopholes or gaps "present the sponsor system followed the approval system under government monopoly right to decide the issue of regulation, the market is not conducive to the rational allocation of resources and effective. in contrast, the registration system tends discretion to issue of shares to the market players by investors to determine their own stock investment value, it is the responsibility of government to do to maintain market order, emphasis on information disclosure and afterwards punish violations, and improve relevant laws and regulations.

\section{Conclusions}

As mentioned above, IPO registration system to implement China's securities market conditions are not ripe now to actively prepare the ground work to the full, complete and accurate information disclosure as the center, strengthen capital constraints, market constraints and integrity constraints; Listed Companies We must clear legal responsibility for the information disclosure; securities intermediary service institutions must clearly bear its objective, impartial oversight responsibilities; other aspects of the construction of the securities market, including securities legal system construction, securities litigation, and the building system should gradually improve. Only in this way, China's stock market IPO registration system can really play its due role, so as to promote the healthy development of China's securities market issuance.

\section{References}

[1] Xu Sun, Li Jingyuan. Economic Review, Vol. 6 (2004) No 53, p.25-26

[2] Liu Chunling, Wang Qunyong. Economic Review, Vol. 12 (2005) No 27, p.74-76

[3] He Qiang, Jing Jianfen, Hou XuSiem. Securities Times, Vol. 30 (2004) No 19, p.144-145

[4] Wang Kuailiang. Shanghai Securities News, Vol. 29 (2008) No 27, p.21-23

[5] Gu Qing. Southwest University of Finance and Economics, Vol. 8 (2003) No 27, p.57-60 